\title{
Nanotoxicity: emerging concerns regarding nanomaterial safety and occupational hard metal (WC-Co) nanoparticle exposure
}

This article was published in the following Dove Press journal:

International Journal of Nanomedicine

I December 2016

Number of times this article has been viewed

\author{
Andrea L Armstead ${ }^{1,2}$ \\ Bingyun $\mathrm{Li}^{\mathrm{I}-3}$ \\ 'Department of Orthopaedics, School \\ of Medicine, ${ }^{2}$ School of Pharmacy, \\ West Virginia University, ${ }^{3}$ Mary \\ Babb Randolph Cancer Center, \\ Morgantown, WV, USA
}

\begin{abstract}
As the number of commercial and consumer products containing engineered nanomaterials (ENMs) continually rises, the increased use and production of these ENMs presents an important toxicological concern. Although ENMs offer a number of advantages over traditional materials, their extremely small size and associated characteristics may also greatly enhance their toxic potentials. ENM exposure can occur in various consumer and industrial settings through inhalation, ingestion, or dermal routes. Although the importance of accurate ENM characterization, effective dosage metrics, and selection of appropriate cell or animalbased models are universally agreed upon as important factors in ENM research, at present, there is no "standardized" approach used to assess ENM toxicity in the research community. Of particular interest is occupational exposure to tungsten carbide cobalt (WC-Co) "dusts," composed of nano- and micro-sized particles, in hard metal manufacturing facilities and mining and drilling industries. Inhalation of WC-Co dust is known to cause "hard metal lung disease" and an increased risk of lung cancer; however, the mechanisms underlying WC-Co toxicity, the inflammatory disease state and progression to cancer are poorly understood. Herein, a discussion of ENM toxicity is followed by a review of the known literature regarding the effects of WC-Co particle exposure. The risk of WC-Co exposure in occupational settings and the updates of in vitro and in vivo studies of both micro- and nano-WC-Co particles are discussed.
\end{abstract}

Keywords: engineered nanomaterial, occupational exposure, lung disease, cancer, toxicity, particle

\section{Engineered nanomaterials (ENMs), nanotoxicity, and means of exposure}

Because of recent technological and manufacturing advancements, the production and use of ENMs has increased at a rapid pace. The term ENM broadly encompasses a number of nano-sized materials that vary in shape, such as nanotubes, nanowires, or nanoparticles (NPs), which are generally defined as "any material having at least one dimension smaller than $100 \mathrm{~nm} .{ }^{.1}$ Because of their extremely small size and high surface area, NPs offer a number of advantages over traditional "bulk" materials and are suitable for a wide variety of applications in consumer goods, ${ }^{2,3}$ medical devices and diagnostics, ${ }^{4-6}$ pharmaceutical products, ${ }^{4,-10}$ fuel additives, ${ }^{11,12}$ and other industrial uses. ${ }^{13-17}$ As a result, the number of manufactured goods containing NPs is continually rising; in 2006, manufacturers reported that NPs were incorporated in over 600 consumer products worth $\$ 50$ billion in market value, ${ }^{18}$ a number which has doubled to $>1,600 \mathrm{NP}$-containing consumer products in $2013 .^{19}$ 
With the increased use of NPs in such diverse applications, a concomitant risk of exposure exists across consumer households and in commercial occupational settings. NPs exist in our daily environments and are often referred to as "contaminants" of important air, water, and soil resources..$^{20,21}$ Because these NPs are all around us, exposure can occur through mechanisms such as inhalation, ingestion, and dermal exposure. ${ }^{22}$ Additionally, emerging evidence suggests that humans may also be exposed to NPs internally, which may be generated in situ due to orthopedic surgical implant wear. ${ }^{23,24}$ These potential routes of NP exposure are summarized graphically in Figure 1. Importantly, the route of exposure ultimately determines which body system or specific tissues the NPs interact with which in turn determines the effects of NP exposure such as toxicity ${ }^{25,26}$ or alterations in physiological function. ${ }^{27}$

The effects of NP exposure can be divided into primary and secondary categories (Figure 1), depending upon the extent of exposure. Primary effects resulting from direct cellular NP contact may include toxicity, oxidative stress, DNA damage, and inflammation. ${ }^{1,28,29}$ Because of their small size, NPs may translocate through tissue barriers into the blood, where they can circulate and eventually deposit in other organs, thereby generating a secondary NP exposure. Secondary effects may include toxicity at the site of NP deposition, in organs such as the liver, spleen, or kidneys, stimulation of systemic inflammation or alterations in systemic function. ${ }^{1,28-30}$ The first three routes of exposure occur through external NP sources, but there is emerging evidence which indicates that humans may also be exposed internally, when orthopedic or surgical implant wear NPs are released locally from the implant site. ${ }^{23,31,32}$ Most commonly, humans are exposed to NPs in their environments through the pulmonary route, by inhaling airborne NPs during normal breathing. ${ }^{27,33}$

Despite their potential toxic properties, it is worth mentioning that certain NPs have distinct advantages that outweigh the risk of use and have greatly improved consumer products on the market today, such as sunscreens and cosmetics. ${ }^{22}$ For example, titanium dioxide NPs present in sunscreens and cosmetic products are highly beneficial, offering excellent protection from sun exposure, thus protecting the skin against UV damage and preventing sunburn. NPs have been approved for use under these conditions; however, the long-term effects of titanium dioxide NPs on aquatic life in contaminated water sources (lakes, oceans, etc) remain an important concern for future research.

As a direct result of the increased use of NPs and likelihood of exposure, the study of the acute and chronic effects of NP exposure has recently emerged as the field of "nanotoxicology". ${ }^{34}$ Currently, there is no standard approach for NP toxicity testing, and a number of arguments support the implementation of a standard testing procedure, so that results and outcomes can be directly comparable among all NPs tested. However, this remains as a difficult task because the route and realistic amount of exposure (dose) vary greatly

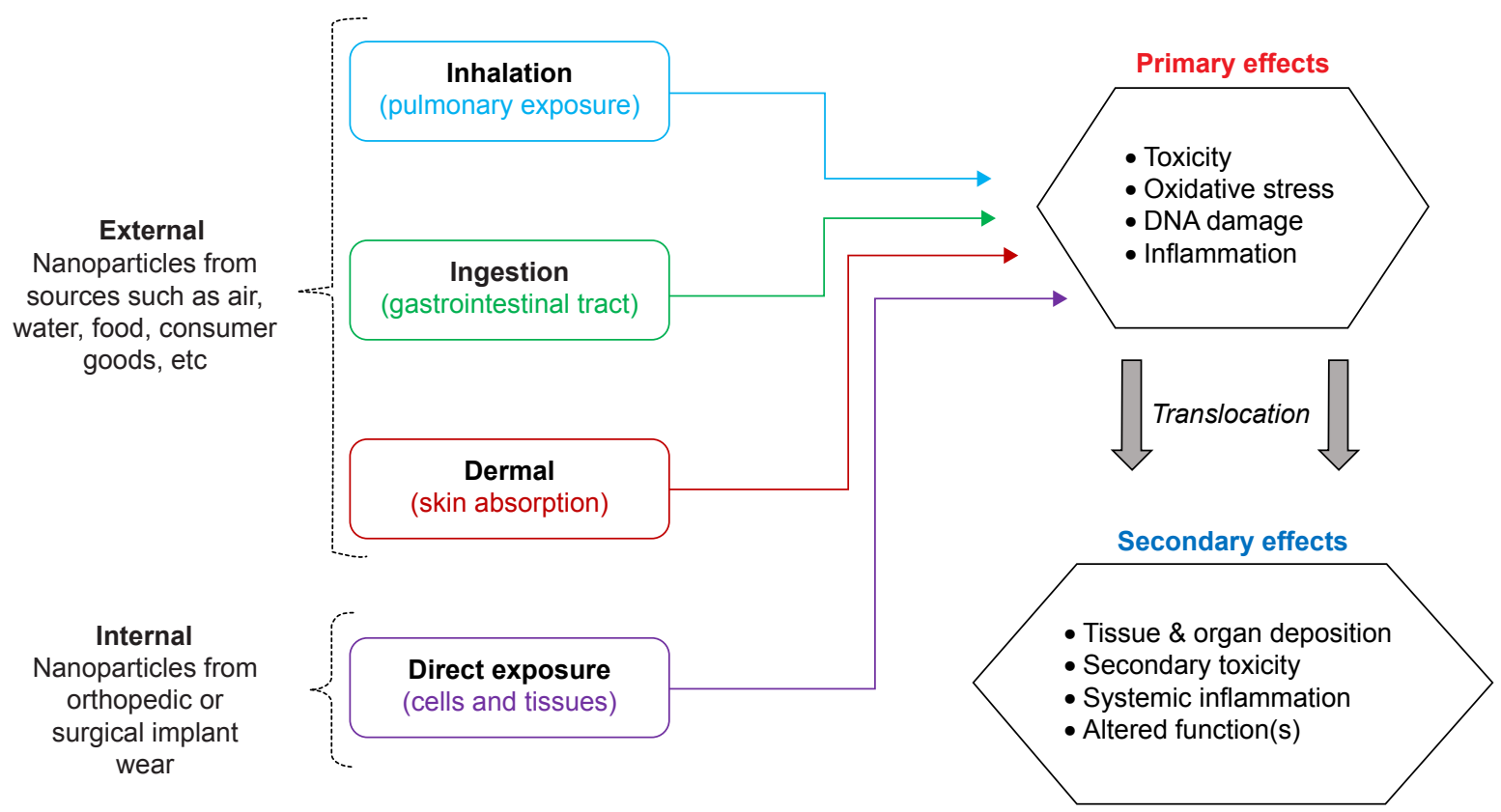

Figure I Routes and potential detrimental effects of nanoparticle exposure. 
Table I Important components of NP toxicity testing

\begin{tabular}{ll}
\hline Characterization & Primary particle size \\
& Agglomerate size in suspension \\
& Size distribution range \\
& Elemental composition \& contaminant levels \\
& Zeta potential \\
& Particle shape/morphology \& density \\
& Mass per volume (mg/mL) \\
Dosage metrics & Surface area ( $\left.\mu m^{3}\right)$ \\
& Particle number \\
& Single or multi-dose \& dose frequency \\
& In vitro: cell selection, mono- or co-culture model \\
& In vitro: assay selection (MTT, LDH, etc) \\
Model system & In vivo: animal selection (rat, mouse, etc) \\
& In vivo: method of exposure (inhalation, intra- \\
& tracheal instillation, injection, internal wear \\
& debris, etc) \& exposure duration \\
& In vivo: sample collection (fluid, tissue, organ, etc) \\
\hline
\end{tabular}

Abbreviations: LDH, lactate dehydrogenase; NP, nanoparticle.

depending on the particular NP in question. ${ }^{35}$ In order to define the toxic potential of NPs, several key factors must be addressed (summarized in Table 1). ${ }^{1,29,34}$ First, it is imperative to characterize NPs in terms of size, shape, and properties (ie, morphology, surface charge), so that the observed effects can be attributed to a particular property or characteristic. Next, an appropriate dosage metric must be selected for the NPs to be examined. In the literature, NP dosages have been reported as concentration per volume or mass $(\mathrm{mg} / \mathrm{mL}$ or $\mathrm{mg} / \mathrm{kg}$ ), as reactive surface area $\left(\mathrm{cm}^{2}\right)$ or as particle number in solution, calculated based on NP size..$^{35}$

In addition to particle characterization and selection of the dosing metric, an appropriate model must be selected for toxicity testing. Typically, in vitro cell-based models are the starting point due to lower cost and relative ease of execution compared to in vivo animal-based model systems. ${ }^{36}$ In vitro systems require small amounts of NPs for testing and allow for dose-response testing and sample collection over time in various systems, such as cells or tissues. ${ }^{36}$ Primary or commercial cells are commonly used for ENM toxicity testing and cell selection for a given assay is frequently based on the potential route of NP exposure; some examples of in vitro models are summarized in Table 2. Aside from the advantage of being "fast and cheap," in vitro models can be used to estimate toxico-kinetic parameters, identify potential target organ toxicity, and help define appropriate NP dosages for in vivo studies, which help to reduce the number of experimental animals required for nanotoxicity research.

Although in vitro models and toxicity assays are in general reliable and used frequently, several groups have reported NP interference with commonly used cell-based assays, ${ }^{37,38}$ bringing into question whether the results are accurate or whether they are simply artifacts generated because of NP interference with the assay mechanism. ${ }^{38,39}$ To address this issue, a number of control experiments are required to identify any potential NP assay interference, and these effects must be considered while interpreting the final results.

Although they offer a number of advantages, cell-based systems are limited and generally demonstrate the effects of NPs within a very specific and small compartment compared to whole-animal in vivo models..$^{40}$ Animal models may offer more realistic insights as to the effects of NP exposure in humans because the body systems can be utilized as a whole, with all of its cells, tissues, and organs interacting with the NPs as would be encountered in a realistic exposure scenario. ${ }^{40}$

Since there are a number of NP exposure routes for humans, a number of in vivo exposure approaches must be used such that the effects of the NP on the appropriate tissue or organ system can be identified. Commonly used in vivo NP exposure routes are summarized Table 3 , including NP inhalation, intra-tracheal instillation (IT), injection, and ingestion or gavage. As mentioned earlier, NP inhalation and pulmonary exposure are most common in humans and

Table 2 Examples of in vitro models used in NP toxicity testing

\begin{tabular}{|c|c|c|c|c|}
\hline Cell type & NPs studied & NP size & NP dose & References \\
\hline Human lung carcinoma (A549) & Cerium dioxide $\left(\mathrm{CeO}_{2}\right)$ & $10 \mathrm{~nm}$ & $6.25,25$, or $100 \mu \mathrm{g} / \mathrm{mL}$ & 105 \\
\hline Human hepatocyte $(\mathrm{C} 3 \mathrm{~A})$, human colon & Gold $(\mathrm{Au})$ Cerium dioxide $\left(\mathrm{CeO}_{2}\right)$ & $35 \mathrm{~nm}$ & $0-1,000 \mu \mathrm{g} / \mathrm{mL}$ & 21 \\
\hline adenocarcinoma (CaCo-2), primary trout hepatocytes & & $25 \mathrm{~nm}$ & & \\
\hline Human fibroblasts, peripheral blood mononuclear & Cobalt chromium (CoCr) & $30 \mathrm{~nm}$ & $\mathrm{I}-5,000 \mu \mathrm{m}^{3} /$ well & $106-108$ \\
\hline cells, macrophages & & $3 \mu \mathrm{m}$ & & \\
\hline Hepatocellular carcinoma (HepG2) & Silicon dioxide $\left(\mathrm{SiO}_{2}\right)$ & $43 \mathrm{~nm}$ & $25,50,100,200 \mu \mathrm{g} / \mathrm{mL}$ & 109 \\
\hline Human lung epithelial cells (BEAS-2B) & Titanium dioxide $\left(\mathrm{TiO}_{2}\right)$ & $25 \mathrm{~nm}$ & $5,10,20,40 \mu \mathrm{g} / \mathrm{mL}$ & 110 \\
\hline \multirow[t]{3}{*}{ Rat alveolar macrophages (RAW 264.7) } & Crystalline silica (DQI2) & $960 \mathrm{~nm}$ & $\mathrm{I}, 5,10,40 \mu \mathrm{g} / \mathrm{cm}^{2}$ & 111 \\
\hline & Zinc oxide $(\mathrm{ZnO})$ & $10 \mathrm{~nm}$ & & \\
\hline & Magnesium oxide (MgO) & $8 \mathrm{~nm}$ & & \\
\hline
\end{tabular}

Abbreviation: NP, nanoparticle. 
Table 3 Examples of in vivo exposure models used in NP toxicity testing

\begin{tabular}{|c|c|c|c|c|c|}
\hline NP delivery method & Animal model & NPs studied & NP size & NP dose & References \\
\hline \multirow[t]{2}{*}{ Inhalation } & Mouse & Cadmium oxide ( $\mathrm{CdO})$ & $15 \mathrm{~nm}$ & $250 \mu \mathrm{g} / \mathrm{m}^{3}$ for $3 \mathrm{~h} /$ day $\times 7$ days & 112 \\
\hline & Rat & Magnetite $\left(\mathrm{Fe}_{3} \mathrm{O}_{4}\right)$ & $1.3 \mu \mathrm{m}$ & $\begin{array}{l}4.7,16.6,52.1 \mu \mathrm{g} / \mathrm{m}^{3} \text { for } 6 \mathrm{~h} / \text { day } \\
\times 5 \text { days } / \text { week } \times 13 \text { weeks }\end{array}$ & 113 \\
\hline \multirow[t]{2}{*}{ Intra-tracheal instillation } & Rat & Cerium dioxide $\left(\mathrm{CeO}_{2}\right)$ & $191 \mathrm{~nm}$ & $10,100,400 \mu \mathrm{g}$ per rat & 114 \\
\hline & Mouse & Chitosan & $633 \mathrm{~nm}$ & $2 \mathrm{mg} / \mathrm{kg}$ & 115 \\
\hline \multirow[t]{2}{*}{ Injection } & $\begin{array}{l}\text { Mouse } \\
\text { (periarticular injection) }\end{array}$ & Cobalt chromium (CoCr) & $\begin{array}{l}32 \mathrm{~nm} \\
2.9 \mu \mathrm{m}\end{array}$ & $\begin{array}{l}1.2 \times 10^{6} \mu \mathrm{m}^{3} / 25 \mathrm{~g} \\
\mathrm{I} \text { injection/week } \times 2 \text { weeks }\end{array}$ & 116 \\
\hline & Rats (articular injection) & Cobalt chromium (CoCr) & $60 \mathrm{~nm}$ & $\begin{array}{l}0.05,0.25,1.25 \mu \mathrm{g} / \mathrm{mL} \\
\text { I injection } / \text { week } \times 10 \text { weeks }\end{array}$ & 117 \\
\hline Ingestion (via GI tract) & $\begin{array}{l}\text { Daphnia magna, Cyprius } \\
\text { carpo (fish species) }\end{array}$ & $\begin{array}{l}\text { Gold }(\mathrm{Au}) \\
\text { Cerium dioxide }\left(\mathrm{CeO}_{2}\right)\end{array}$ & $\begin{array}{l}35 \mathrm{~nm} \\
25 \mathrm{~nm}\end{array}$ & $0-10 \mu \mathrm{g} / \mathrm{mL}$ & 21,118 \\
\hline
\end{tabular}

Abbreviations: NP, nanoparticle; GI, gastrointestinal tract.

are therefore the most frequent routes by which experimental animals are exposed in nanotoxicity studies. However, not all NPs are suitable for aerosolization and for the purposes of an inhalation chamber, so alternatively, pulmonary NP exposure can be achieved via IT. ${ }^{41}$ IT is a highly reproducible, direct method for depositing NP within the lungs, and NPs delivered in this manner have very similar lung distribution to NP inhalation, ${ }^{41}$ therefore, IT is considered as an excellent approach for the pulmonary delivery of NP. In addition to pulmonary routes of exposure, animals may also be exposed to NP via injection for the purposes of systemic or local NP exposure. Intra-peritoneal (IP) or intravenous (IV) NP injections can be used to achieve systemic NP exposure, as the NPs circulate through the vasculature and may deposit in organs such as the liver, spleen, or kidneys. Injection may also be used to achieve localized NP exposure within articular locations, such as the knee or hip, or may be used to target subcutaneous tumors.

\section{Industrial hard metal (WC-Co) applications and exposure}

Among the plethora of NPs gaining industrial use and popularity is tungsten carbide cobalt (WC-Co), which is a hard composite metal known for its extreme hardness, stability, and sharpness. ${ }^{42,43}$ The use of WC-Co NPs as a spray coating on heavy machinery, drill bits, and saw blades substantially increases strength, durability, and resistance to wear, which drastically improves the operating lifetimes in industrial applications. ${ }^{42,43}$ In particular, WC-Co coatings are popular in mining and drilling industries, where maintenance of sharp saw blades and drills is of critical importance.

Despite the improved durability and strength of WC-Co NP coatings compared to other conventional materials, these coatings do not last long and eventually wear out with extended use and over time. As a result, airborne WC-Co dusts containing particles of varying size can be generated during use. ${ }^{44}$ These airborne WC-Co "dusts" present an occupational exposure hazard not only in hard metal manufacturing facilities but also in mining and drilling industries where these WC-Co-coated implements are used extensively in enclosed environments. Typical WC-Co dusts encountered in industrial environments have a reported size range of several microns down to highly respirable particles in the nano-size range. ${ }^{45}$

Although exposure to WC-Co containing dusts has been identified as an occupational workplace hazard by the National Institutes of Occupational Safety and Health, ${ }^{46}$ exposure limits for WC-Co dusts and powders remain undefined. Daily occupational exposures likely vary, as it is extremely difficult to predict an accurate exposure given the variability in dust generation and ventilation among worksites. Therefore, it is difficult to estimate what a relevant WC-Co dosage or concentration should be for experimental models. The existing exposure limits for cobalt metal and ionic cobalt $t^{47-49}$ are difficult to translate to WC-Co exposure; ionic cobalt is soluble in physiological fluids and cell culture buffers, and exposure modality would experience different physiological effects than exposure to a solid (non-soluble) WC-Co composite NP. ${ }^{47-49}$ Additionally, cobalt content can vary, depending on the application, and the dusts generated may not have uniform composition between multiple industrial sites. ${ }^{50}$ More importantly, the combination of WC-Co is more toxic than $\mathrm{Co}, \mathrm{W}$, or WC particles alone (see section entitled Defining hard metal (WC-Co) toxicity: in vitro and in vivo studies). Therefore, understanding the toxic effects of hard metal WC-Co particles is crucial in order to develop occupational exposure guidelines.

\section{Risk of WC-Co exposure: hard metal lung disease (HMLD) prognosis and cancer risk}

Exposure to "hard metal dust" containing WC-Co is well associated with the occurrence of occupational asthma and 
is a known risk factor for the development of HMLD. ${ }^{44,51-59}$ Diagnosis of HMLD is a challenge, as symptoms are general and often mistaken for other respiratory ailments: patients often report difficulty breathing and present with reduced lung capacity, progressive lung inflammation, and eventual fibrosis..$^{57,60,61}$ HMLD has been reported in hard metal manufacturing and oil and mining/drilling industries, where workers were exposed to WC-Co dusts or fumes on a daily basis for a number of years prior to diagnosis. ${ }^{44,51,62-65}$ Currently, treatments are limited and no disease-specific therapy or diagnostic tool exists. There has been some success in treating HMLD with corticosteroids or immunosuppressive therapies, ${ }^{66,67}$ typically resulting in moderate attenuation of breathing challenges and delayed onset of further symptoms (ie, fibrosis and fluid in the lungs), but in most cases, avoidance of further hard metal exposure is the recommended course of action.

It has recently been established that the defining characteristic of HMLD is the presence of "bizarre, cannibalistic, multinucleated giant cells" in lung biopsy specimens of workers exposed to WC-Co. ${ }^{57,61,63,65,68,69}$ These giant cell complexes are thought to originate from macrophages which have engulfed WC-Co particles, which then stimulate inflammatory and fibrotic processes in the surrounding lung tissue. ${ }^{57,63,69}$ In some cases, WC-Co particle "deposits" have been found in biopsy specimens, confirming causative exposure to WC-Co dust and HMLD diagnosis. ${ }^{62,63,69,70}$ It has been hypothesized that there may be an allergic reaction or a genetic predisposition which may contribute to the development of HMLD in certain individuals. ${ }^{71}$

There is also accumulating evidence that patients with HMLD are at a twofold increased risk of developing lung cancer. ${ }^{54,56}$ It has been argued that the generation of reactive oxygen species by WC-Co particles, which may directly cause DNA damage, along with the ability of cobalt ions to inhibit DNA repair mechanisms, may play a synergistic role in the development of lung cancer in HMLD patients. ${ }^{56}$ However, this hypothesis is yet to be verified in vivo and the relationship between the inflammatory disease state and development of lung cancer remains unclear.

\section{Defining hard metal (WC-Co) toxicity: in vitro and in vivo studies}

Early data concerning the effects of inhaled WC-Co dusts first emerged in the 1960s and continued through the 1980s, providing researchers the foundation to further explore the toxic effects of hard metal exposure using in vitro ${ }^{71-88}$ and in vivo ${ }^{72,89-96}$ models. Although cobalt itself was originally considered the causative agent of HMLD, several studies demonstrated that this is not the case and the disease mainly develops due to the simultaneous presence of WC with Co. ${ }^{71,74,76-79,90,91}$ It is currently understood that the combination of WC-Co is more toxic than $\mathrm{Co}$, W, or WC particles alone, both in vitro and in vivo, ${ }^{71,72,74,78,79,81,85,90,91,93,94,97-99}$ but the reason for this enhanced toxicity is still not well defined.

On the in vitro side, the effects of direct WC-Co particle exposure were examined by a number of research groups in terms of cell viability, apoptogenic potential, genotoxicity, oxidative stress, and DNA damage in multiple cell lines of various origins. The major outcomes of these early in vitro studies are summarized in Table 4, where the cell type, particle size, and dosage parameter is noted for each study. In alveolar macrophages, $2 \mu \mathrm{m}$ WC-Co particles caused significant toxicity after $24 \mathrm{~h}$ of exposure at concentrations ranging from 50 to $1,667 \mu \mathrm{g} / \mathrm{mL}$, but were less toxic toward type II pneumocytes under these conditions, ${ }^{72,99}$ confirming pulmonary WC-Co toxicity in a relevant in vitro model. Toxicity has also been reported in mouse peritoneal macrophages, where WC-Co particles ranging from 2 to $4 \mu \mathrm{m}$ caused toxicity within 6 $\mathrm{h}$ of exposure at concentrations ranging from 50 to $300 \mu \mathrm{g} /$ $\mathrm{mL} .{ }^{79,98,100}$ In human peripheral blood mononuclear cells, exposure to micron-sized WC-Co particles caused apoptosis, DNA damage, genotoxicity, and alterations in gene expression after exposure times as short as $15 \mathrm{~min}$ and up to $6 \mathrm{~h}^{\text {.1, } 82,92,101}$ Additionally, a number of these studies compared the toxicity of WC-Co, WC, or Co particles and determined that the interaction of WC with Co significantly enhances the toxicity of the composite compared to any single component. ${ }^{71,74,79,101}$

There are fewer studies that have examined the effects of nano-WC-Co particles; however, nano-WC-Co toxicity has been reported in human keratinocytes, liver carcinoma cells, oligodendroglial precursor cells, and neurons, at concentrations ranging from 3 to $30 \mu \mathrm{g} / \mathrm{mL}$ and exposure times from $1 \mathrm{~h}$ up to 3 days. ${ }^{74,75,78}$ Internalization of nanoWC-Co has been reported in the keratinocytes (epidermal cells) after 2 days of exposure, which suggested that nanoWC-Co could potentially be absorbed through the skin. ${ }^{74,75}$ Nano-WC-Co toxicity has also been reported in rainbow trout gill cells, murine epidermal cells, and fibroblasts at concentrations $<100 \mu \mathrm{g} / \mathrm{mL}$ for $3 \mathrm{~h}$ and up to 3 days. ${ }^{83,84}$ Nano-WC-Co has been shown to exert genotoxic effects by affecting the expression of genes involved in cellular apoptosis and stress responses. ${ }^{75}$ In addition, nano-WC-Co has been found to induce greater cellular toxicity and higher levels of oxidative stress than micro-WC-Co particles of the same composition under identical conditions (Figure 2). ${ }^{86}$ These studies are consistent with the other reports where the 
Table 4 Summary of in vitro WC-Co toxicity studies

\begin{tabular}{|c|c|c|c|}
\hline Cell type & Particle size \& dosage & Major outcome(s) & References \\
\hline $\begin{array}{l}\text { Primary rat type II } \\
\text { pneumocytes }\end{array}$ & $\begin{array}{l}2 \mu \mathrm{m} \\
50 \mu \mathrm{g} / \mathrm{mL} \text { WC-Co }\end{array}$ & $\begin{array}{l}\text { No changes in the levels of TNF } \alpha \text {, IL-I, fibronectin or } \\
\text { cystatin-C (compared to control) were observed after } \\
\text { WC-Co exposure for } 12 \text { or } 24 \mathrm{~h} \text { in isolated rat type II } \\
\text { pneumocytes }\end{array}$ & 72 \\
\hline $\begin{array}{l}\text { Human colon adenocarcinoma } \\
\text { (CaCo-2), human } \\
\text { keratinocytes (HaCaT), human } \\
\text { lung carcinoma (A549), OLN- } \\
93 \text { oligodendro-glial precursor } \\
\text { cells, rat neurons, astrocytes }\end{array}$ & $\begin{array}{l}145 \mathrm{~nm} \\
3.3,6.6,8.25, \mathrm{II}, \mathrm{I} 6.5 \text {, or } \\
33 \mu \mathrm{g} / \mathrm{mL} \text { WC-Co }\end{array}$ & $\begin{array}{l}\text { WC-Co particles exhibited significant toxicity at a } \\
\text { concentration of } 33 \mu \mathrm{g} / \mathrm{mL} \text { after } 3 \text { days of exposure to } \\
\text { CaCo-2, HaCaT, and A549 cells. Significant toxicity was also } \\
\text { observed in astrocytes after exposure to } 3.3 \mu \mathrm{g} / \mathrm{mL} \text { and higher } \\
\text { WC-Co concentration after I and } 3 \text { days. Primary rat neurons } \\
\text { were not sensitive to WC-Co toxicity. Additionally, WC-Co } \\
\text { particles were internalized into the cytoplasm of HaCaT, } \\
\text { A549, and OLN- } 93 \text { cells after } 2 \text { days }\end{array}$ & 74 \\
\hline $\begin{array}{l}\text { Human peripheral blood } \\
\text { mononucleated cells (PMBC) }\end{array}$ & $\begin{array}{l}\text { I } \mu \mathrm{m} \\
10,50, \text { or } 100 \mu g / m L ~ W C-C o \\
\text { or Co }\end{array}$ & $\begin{array}{l}\text { After } 15 \text { min exposure to WC-Co, PMBC demonstrated I.5- } \\
\text { fold increase in DNA damage, marked by increased formation } \\
\text { of micronuclei due to oxidative stress, compared to control } \\
\text { and Co particle treatment alone }\end{array}$ & 119 \\
\hline $\begin{array}{l}\text { Rainbow trout gill cells } \\
\text { (RTgill-WI) }\end{array}$ & $\begin{array}{l}145 \mathrm{~nm} \\
8.25,16.5 \text {, or } 33 \mu \mathrm{g} / \mathrm{mL} \\
\text { WC-Co }\end{array}$ & $\begin{array}{l}\text { WC-Co caused significant reduction in cell viability after } 3 \mathrm{~h} \\
\text { and } 3 \text { days of exposure in RTgill cells. WC-Co particles were } \\
\text { also found to be internalized into the cytoplasm after } 2 \text { days }\end{array}$ & 120 \\
\hline $\begin{array}{l}\text { Human keratinocyte }(\mathrm{HaCaT}) \\
\text { and hepato-cellular liver } \\
\text { carcinoma (HepG2) cells }\end{array}$ & $\begin{array}{l}\text { I } 45 \mathrm{~nm} \\
7.5, \mathrm{I} 5 \text {, or } 30 \mu \mathrm{g} / \mathrm{mL} \text { WC-Co }\end{array}$ & $\begin{array}{l}\text { WC-Co internalization in } \mathrm{HaCaT} \text { was confirmed; however, } \\
\text { WC-Co did not cause significant toxicity at the concentrations } \\
\text { studied after I h, } 3 \mathrm{~h} \text {, or } 3 \text { days. WC-Co particles did not } \\
\text { induce reactive oxygen species (ROS) or DNA micronuclei } \\
\text { under the conditions tested }\end{array}$ & 78 \\
\hline
\end{tabular}

$\begin{array}{ll}\text { Mouse peritoneal } & 2 \mu \mathrm{m} \\ \text { macrophages } & 50,100,200, \text { or } 300 \mu \mathrm{g} / \mathrm{mL} \text { of } \\ & \text { WC-Co, Co, or WC }\end{array}$

After 18-24 h of exposure, WC-Co caused significant

toxicity, marked by increased LDH release and significant induction of oxidative stress compared to control. Activated oxygen species were implicated in associated DNA damage (micronuclei) in macrophages

Human keratinocytes $(\mathrm{HaCaT}) \quad 62 \mathrm{~nm}$

$33 \mu \mathrm{g} / \mathrm{mL}$ WC-Co

WC-Co exposure caused significant changes in gene

$79,80,98,121,122$ expression, such as HIFI, after $3 \mathrm{~h}$ and 3 days of exposure. WC-Co responsive genes were involved in cellular death and stress responses

Mouse peritoneal

$2-4 \mu \mathrm{m}$ macrophages

$0-500 \mu \mathrm{g} / \mathrm{mL}$ of carbides: WC, $\mathrm{TaC}, \mathrm{SiC}, \mathrm{NbC}, \mathrm{Fe}, \mathrm{TiC}$, $\mathrm{Mo}_{2} \mathrm{C}$; all plus $6 \% \mathrm{Co}$ The addition of $6 \%$ Co particles to each of the "carbide" particles significantly enhanced the toxicity of WC, TiC, and $\mathrm{NbC}$ in macrophages after $18 \mathrm{~h}$ exposure, marked by increased levels of LDH release compared to control and the various carbide particles alone. Enhanced toxicity was attributed to the interaction of Co with the carbides

Human peripheral blood mononuclear cells (PMBC)

$<\mathrm{I} \mu \mathrm{m}$ $100 \mu \mathrm{g} / \mathrm{mL}$ WC-Co

Human PMBC

Human PMBC and human monocytes

Human peripheral lymphocytes and mouse fibroblasts (3T3)
$<\mathrm{I} \mu \mathrm{m}$ $33.3,45$, or $100 \mu \mathrm{g} / \mathrm{mL}$ WC-Co or WC

$<\mathrm{I} \mu \mathrm{m}$ $100 \mu \mathrm{g} / \mathrm{mL}$ WC-Co or WC

$2 \mu \mathrm{m}$

$100 \mu \mathrm{g} / \mathrm{mL}$ WC-Co, WC, or Co
Exposure to WC-Co particles for 15 min caused altered gene expression after 6 and up to $24 \mathrm{~h}$ post-exposure in $\mathrm{PMBC}$, including activation of HIF- $\mathrm{I} \alpha$, $\mathrm{p} 53$, and altered expression of HMOXI which is involved in oxidative stress response mechanisms

WC-Co particles caused cellular apoptosis, marked by annexin- $V$ staining, after $15 \mathrm{~min}$ and $6 \mathrm{~h}$ of exposure. Apoptosis was induced via the caspase- 9 pathway and DNA fragmentation was significantly elevated in WC-Co exposed cells compared to WC alone

A $24 \mathrm{~h}$ exposure to WC-Co caused significant up-regulation of apoptosis and stress response genes in both PMBC and monocytes, namely BNIP3, which is involved in mitochondrial mediated cell death

In lymphocytes, WC-Co caused significant induction of DNA strand breaks after 15 min of exposure, attributed to oxidative stress damage, and caused extensive DNA damage in isolated 3T3 cellular DNA compared to WC or Co particles alone 
Table 4 (Continued)

\begin{tabular}{|c|c|c|c|}
\hline Cell type & Particle size \& dosage & Major outcome(s) & References \\
\hline Mouse epidermal cells (JB6) & $\begin{array}{l}80 \mathrm{~nm}, 4 \mu \mathrm{m} \\
25,37.5,50,75 \text {, or } 150 \mu \mathrm{g} / \mathrm{mL} \\
\text { WC-Co }\end{array}$ & $\begin{array}{l}\text { Nano-WC-Co induced greater oxidative stress and hydroxyl } \\
\text { radicals, marked by significantly decreased cellular GSH levels, } \\
\text { in JB6 cells compared to micro-WC-Co. Nano-WC-Co also } \\
\text { stimulated induction of AP-I and NF-kappaB and increased } \\
\text { cellular proliferation in JB6 cells compared to micro-WC-Co } \\
\text { under identical conditions }\end{array}$ & 84 \\
\hline $\begin{array}{l}\text { Rat alveolar macrophages } \\
\text { (AM) and type II pneumocytes }\end{array}$ & $\begin{array}{l}2 \mu \mathrm{m} \\
83,417, \text { or } 1,667 \mu \mathrm{g} / \mathrm{mL} \\
\text { WC-Co or Co }\end{array}$ & $\begin{array}{l}\text { After } 24 \text { h exposure to WC-Co, significant toxicity was } \\
\text { observed in AM, but not in type II pneumocytes, compared to } \\
\text { controls. However, type II cells were more sensitive toward } \\
\text { Co toxicity than AM, in the absence of WC components }\end{array}$ & 99 \\
\hline Lung epithelial cells & $\begin{array}{l}4 \mu \mathrm{m} \text { and } 80 \mathrm{~nm} \text { of WC-Co } \\
0.1-1,000 \mu \mathrm{g} / \mathrm{mL} \\
\text { for } 0.5-48 \mathrm{~h}\end{array}$ & Nano-WC-Co was more toxic than micro-WC-Co & 86 \\
\hline $\begin{array}{l}\text { Lung epithelial cells, } \\
\text { macrophages, and their } \\
\text { co-culture }\end{array}$ & $\begin{array}{l}80 \mathrm{~nm} \text { of WC-Co } \\
\mathrm{I}-\mathrm{I}, 000 \mu \mathrm{g} / \mathrm{mL} \\
\text { for } 2-48 \mathrm{~h}\end{array}$ & $\begin{array}{l}\text { Toxicity of nano-WC-Co was cell dependent, macrophages in } \\
\text { the co-culture may play a protective role against nano-WC- } \\
\text { Co-mediated toxicity, and nano-WC-Co exposure stimulated } \\
\text { the MI phenotype of macrophages }\end{array}$ & 87 \\
\hline
\end{tabular}

Abbreviations: TNF, tumor necrosis factor; IL, interleukin; LDH, lactate dehydrogenase; WC-Co, tungsten carbide cobalt.
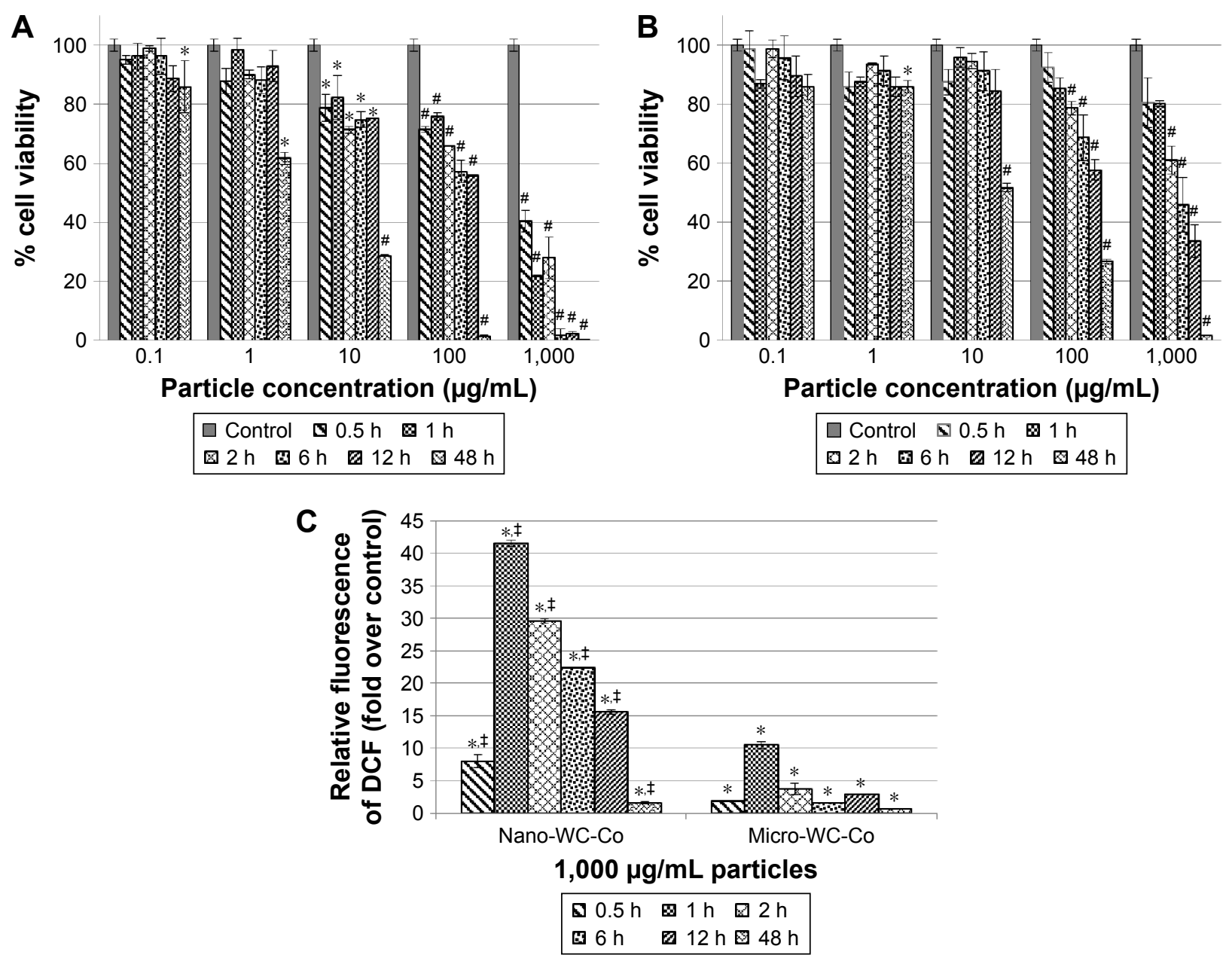

Figure 2 Cell viability after (A) nano-WC-Co and (B) micro-WC-Co particle exposure and (C) oxidative stress indicated by DCF fluorescence after exposure to I, $000 \mu \mathrm{g} / \mathrm{mL}$ nano- and micro-WC-Co particles. ${ }^{86} * P<0.05$, ${ }^{\# P}<0.00$ I compared to control, ${ }^{\ddagger} P<0.05$ compared to micro-WC-Co.

Note: Reproduced from Armstead AL, Arena CB, Li B. Exploring the potential role of tungsten carbide cobalt (WC-Co) nanoparticle internalization in observed toxicity toward lung epithelial cells in vitro. Toxicol Appl Pharmacol. 20I4;278(I):I-8. ${ }^{86}$

Abbreviations: DCF, 2', $7^{\prime}$-dichlorofluorescein; WC-Co, tungsten carbide cobalt. 
enhanced toxicity of nano-sized over micro-sized particles has been clearly established. ${ }^{22,26,102,103}$

Although the effects of WC-Co particles have been established in multiple cell lines of varying origin, most of these studies used mono-culture systems in their examination of WC-Co particle toxicity, which may not provide an accurate assessment of what happens during/after WC-Co exposure since the local environment of the lung is highly dynamic and contains more than a single cell type. In a recent study, ${ }^{87}$ the inflammatory response toward nano-WC-Co particles in macrophages and the toxicity of WC-Co have been examined using a co-culture model of lung epithelial cells and macrophages to more closely represent the dynamic tissue environment of the lung. Nano-WC-Co exposure has stimulated an inflammatory response in macrophages, marked by high levels of interleukin-12 (IL-12) and IL-1 $\beta$ secretion. ${ }^{87}$ In HMLD, lung inflammation and fibrosis occur in a progressive fashion; hence, it has been speculated that the induction of a pro-inflammatory response in macrophages may be an important factor in HMLD. This idea is supported by another study which has indicated that IL-1 in particular may play a role in pulmonary fibrosis, ${ }^{104}$ and it seems reasonable to suggest that WC-Co may induce a similar type of pulmonary inflammatory response which promotes lung fibrosis after inhalation.

The large majority of previous WC-Co animal studies summarized in Table 5 employed the IT exposure model as the preferred means of delivery for hard metal particles and "dust" in vivo., 52,89-92,94 As noted in Table 5, the in vivo studies examined the effects of WC-Co particles in the

Table 5 Summary of in vivo WC-Co toxicity studies

\begin{tabular}{|c|c|c|c|c|}
\hline $\begin{array}{l}\text { Method of } \\
\text { delivery }\end{array}$ & $\begin{array}{l}\text { Animal model \& } \\
\text { particle size }\end{array}$ & WC-Co dosage & Major outcome(s) & References \\
\hline $\begin{array}{l}\text { Intra-tracheal } \\
\text { instillation (IT) }\end{array}$ & $\begin{array}{l}\text { Rat } \\
\text { Mixed WC-Co } \\
\text { dusts } \sim 0.1 \text { to } 6 \mu \mathrm{m}\end{array}$ & $\begin{array}{l}\text { Single IT bolus at high dose } \\
(\geq 1 \mathrm{mg} / \mathrm{kg} \text { body weight) }\end{array}$ & $\begin{array}{l}\text { At } 6 \text { months following single IT WC-Co exposure, rats } \\
\text { presented with pulmonary edema, alveolar congestion, } \\
\text { and lung fibrosis in regions of deposited WC-Co dusts }\end{array}$ & 89 \\
\hline IT & $\begin{array}{l}\text { Rat } \\
5 \mu \mathrm{m} \text { WC-Co }\end{array}$ & $\begin{array}{l}\text { Single IT bolus at I mg/I00 g body } \\
\text { weight }\end{array}$ & $\begin{array}{l}\text { WC-Co caused high mortality with massive pulmonary } \\
\text { edema, increased macrophage counts, } L D H \text {, albumin and } \\
\text { total protein content at } 24 \mathrm{~h} \text { post-exposure }\end{array}$ & 90 \\
\hline IT & $\begin{array}{l}\text { Rat } \\
5 \mu \mathrm{m} \text { WC-Co }\end{array}$ & $\begin{array}{l}\text { Single and repeated IT bolus at } \\
\mathrm{I}, 5 \text {, or } 10 \mathrm{mg} / \mathrm{kg} \text { body weight }\end{array}$ & $\begin{array}{l}\text { Single IT WC-Co exposure caused acute alveolitis } \\
\text { which persisted for about I month following the IT } \\
\text { bolus. Repeated weekly exposure ( } 4 x \text { for I month) } \\
\text { caused interstitial lung fibrosis and increased lung } \\
\text { hydroxyproline levels in exposed rats }\end{array}$ & 91 \\
\hline IT & $\begin{array}{l}\text { Rat } \\
2 \mu \mathrm{m} \text { WC-Co }\end{array}$ & $\begin{array}{l}\text { Single IT bolus at } 16.6 \mathrm{mg} / \mathrm{kg} \text { body } \\
\text { weight }\end{array}$ & $\begin{array}{l}\text { WC-Co exposure caused significant elevation of LDH, } \\
\text { total protein \& albumin in BAL fluids after I } 2 \mathrm{~h} \text { and up } \\
\text { to } 72 \mathrm{~h} \text { following exposure. In rat type II pneumocytes } \\
\text { isolated after IT exposure, increased induction of } \\
\text { micronuclei was observed, indicating genotoxicity and } \\
\text { DNA damage }\end{array}$ & 92 \\
\hline IT & $\begin{array}{l}\text { Rat } \\
2 \mu \mathrm{m} \text { WC-Co }\end{array}$ & $\begin{array}{l}\text { Single IT bolus at I mg/I00 g body } \\
\text { weight }\end{array}$ & $\begin{array}{l}24 \mathrm{~h} \text { after single IT WC-Co exposure, significant } \\
\text { increases in LDH, total protein, and albumin were found } \\
\text { in BAL fluids. WC-Co did not exert any effects on the } \\
\text { levels of IL-I, TNF } \alpha \text {, fibronectin, or cystatin-C in BAL } \\
\text { fluids of exposed animals }\end{array}$ & 72 \\
\hline IT & $\begin{array}{l}\text { Rat } \\
3 \mu \mathrm{m} \text { WC-Co }\end{array}$ & $\begin{array}{l}\text { Single IT bolus at } 2.5,5 \text {, or } \\
10 \mathrm{mg} / 100 \mathrm{~g} \text { body weight }\end{array}$ & $\begin{array}{l}\text { Pulmonary edema, fibrin formation, and increased } \\
\text { number of inflammatory cells were observed in WC- } \\
\text { Co-exposed rat lungs, along with decreased reactivity to } \\
\text { methacholine, increased levels of nitric oxide synthase } \\
\text { (NOS), LDH, total protein and albumin in BAL fluids }\end{array}$ & 94 \\
\hline IT & $\begin{array}{l}\text { Rat } \\
\text { I } \mu \mathrm{m} \text { WC-Co }\end{array}$ & Single IT bolus at I or $3 \mathrm{mg}$ per rat & $\begin{array}{l}\text { A significant increase in LDH was observed after I, } 4,7 \text {, } \\
\text { and } 30 \text { days of WC-Co exposure and fibrosis alveolitis } \\
\text { developed in rats after } 30 \text { days post-IT exposure }\end{array}$ & 95 \\
\hline IT & $\begin{array}{l}\text { Rat } \\
80 \mathrm{~nm} \mathrm{WC-Co} \\
190 \mathrm{~nm} \mathrm{CeO}_{2}\end{array}$ & $\begin{array}{l}\text { Single IT bolus at } 0-500 \mu \mathrm{g} \text { per rat } \\
24 \mathrm{~h} \text { exposure }\end{array}$ & $\begin{array}{l}\text { A consistent lack of acute local pulmonary inflammation } \\
\text { was observed in terms of the BAL fluid parameters } \\
\text { examined in animals exposed to WC-Co NPs while } \\
\text { significant acute pulmonary inflammation was observed } \\
\text { in the } \mathrm{CeO}_{2} \mathrm{NP} \text { group }\end{array}$ & 96 \\
\hline
\end{tabular}

Abbreviations: BAL, bronchoalveolar lavage; NP, nanoparticle; LDH, lactate dehydrogenase; WC-Co, tungsten carbide cobalt. 
micron-size range, using the mass-per-body weight dosing scheme (ie, $\mathrm{mg} / \mathrm{kg}$ or $\mathrm{mg} / \mathrm{g}$ ), although some variation in particle size was noted in most cases (overall, WC-Co size ranging from 0.1 to $6 \mu \mathrm{m}$ ). Specifically, micro-sized WC-Co particle exposure caused significant pulmonary inflammation in rats, marked by increased bronchoalveolar lavage (BAL) fluid parameters such as lactate dehydrogenase (LDH) and albumin content, compared to control animals, in as little as $24 \mathrm{~h}$ after delivery the of WC-Co IT bolus. ${ }^{72,91,92,95}$ Significant pulmonary edema, interstitial lung fibrosis, alveolar congestion, and alveolitis were also reported in micro-sized WC-Co-exposed animals at 1 and 6 months following a single IT exposure. ${ }^{89,90,95}$ Given this body of literature, the local effects of micro-sized WC-Co following pulmonary exposure have been characterized relatively well, and it is understood that micro-sized WC-Co exerts both acute and chronic effects in vivo.

The local toxicity and potential systemic effects resulting from pulmonary nano-WC-Co exposure have recently been investigated in rats, and surprisingly, an overall lack of toxicity and pulmonary inflammation after $24 \mathrm{~h}$ exposure to a single dose of nano-WC-Co $(50,250$, or $500 \mu \mathrm{g})$ has been observed, while exposure to $\mathrm{CeO}_{2}(400 \mu \mathrm{g}) \mathrm{NPs}$ has resulted in significant increases in the BAL fluid parameters examined (ie, LDH, albumin, and macrophage activation) (Figure 3). ${ }^{96}$ This outcome seems to be perplexing, as most evidence regarding the effects of WC-Co exposure thus far has suggested that nano-WC-Co should cause acute toxicity both in vivo and in vitro, and the doses selected were based on the known literature for other NP generating pulmonary toxicity. The inflammatory response might have been missed since only a single exposure time ( $24 \mathrm{~h}$ ) has been studied, and it is possible that a single exposure at these concentrations in vivo did not generate enough pulmonary toxicity/ inflammation to be effectively detected through the BAL technique $;{ }^{96}$ toxicity and inflammation may have occurred but not at detectable levels after the $24 \mathrm{~h}$ exposure time. It is also possible that the effects of nano-WC-Co exposure
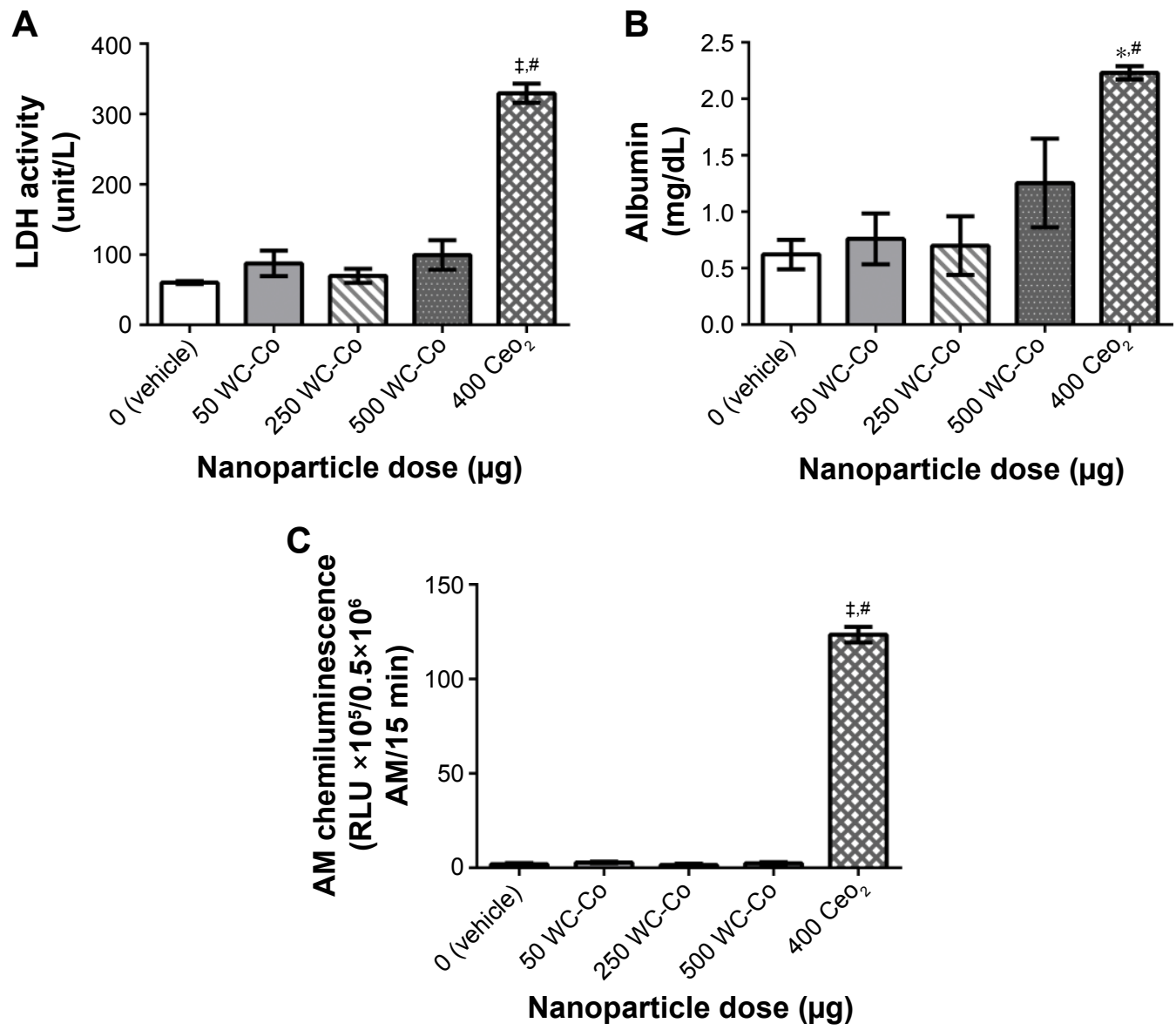

Figure 3 Pulmonary inflammation parameters assessed in the BAL fluid following 24 h exposure to WC-Co and CeO 2 NPs: (A) LDH activity, (B) albumin, and (C) AM chemiluminescence. ${ }^{96}$ Values presented as mean $\pm S D$. $* P<0.05,{ }^{\ddagger} P<0.001$ compared to the vehicle control, and ${ }^{\# P}<0.01$ compared to WC-Co NP exposed groups.

Notes: Reproduced from Armstead AL, Minarchick VC, Porter DW, Nurkiewicz TR, Li B. Acute inflammatory responses of nanoparticles in an intra-tracheal instillation rat model. PLoS One. 2015;10(3):e0I 18778.96

Abbreviations: BAL, bronchoalveolar lavage; LDH, lactate dehydrogenase; AM, alveolar macrophage; SD, standard deviation; NP, nanoparticle; WC-Co, tungsten carbide cobalt. 
may occur in a cumulative fashion (ie, toxicity is observed after repeated or chronic exposures) in vivo; hence, multiple/ repeated exposure may be a prerequisite for WC-Co toxicity in whole animals.

\section{Summary}

NP exposure can occur in various consumer and industrial settings through various means such as inhalation, ingestion, or dermal routes. NP exposure, either via internal or external routes, can produce detrimental effects and has been studied both in vitro and in vivo using cell or animal-based models. Occupational exposure to hard metals such as WC-Co is an important concern in the field of nanotoxicology, since inhalation of WC-Co dusts and particles is known to cause HMLD, marked by progressive lung inflammation, fibrosis, and an increased risk of lung cancer. The current body of research clearly demonstrates that WC-Co particles are highly toxic and are capable of inducing oxidative stress and genotoxicity following exposure, and highlights the detrimental effects of WC-Co NP exposure in occupational settings, including hard metal manufacturing facilities and mining and drilling industries. It is important to define occupational WC-Co exposure limits so that future generations of workers are protected from this harmful disease. However, the pathology of HMLD and presence of the "hallmark" multinucleated giant cells have yet to be successfully reproduced in any animal models. Therefore, future studies should further investigate the mechanism underlying acute and chronic WC-Co toxicity and progression to HMLD in exposed workers.

\section{Acknowledgments}

We acknowledge the financial support from WV NASA EPSCoR, AO Foundation (Project S-13-15L), Osteosynthesis and Trauma Care Foundation, and Orthopaedic Research and Education Foundation. Fellowship funding to A. Armstead was provided by the West Virginia University NANOSAFE graduate fellowship program 2010-12 (formerly WVNano; NSF Cooperative Agreement \#1003907) and by the American Foundation for Pharmaceutical Education (PreDoctoral Fellowship in Pharmaceutical Science, 2012-14). The authors acknowledge the WVU Flow Cytometry Core facility, operated by Kathy Brundage, which is supported by the National Institutes of Health equipment grant number S10OD016165 and the Institutional Development Award (IDeA) from the National Institute of General Medical Sciences of the National Institutes of Health under grant numbers P30GM103488 (CoBRE) and P20GM103434 (INBRE).

\section{Disclosure}

The authors report no conflicts of interest in this work.

\section{References}

1. Schrand AM, Dai L, Schlager JJ, Hussain SM. Toxicity testing of nanomaterials. Adv Exp Med Biol. 2012;745:58-75.

2. Hansen SF, Baun A, Michelson ES, Kamper A, Borling P, Stuer-Lauridsen F. Nanomaterials in consumer products: categorization and exposure assessment. In: Nanomaterials: Risks and Benefits. Linkov I, Steevens J, editors. Dordrecht, the Netherlands: Springer; 2009: 359-367.

3. Stamm H, Gibson N, Anklam E. Detection of nanomaterials in food and consumer products: bridging the gap from legislation to enforcement. Food Addit Contam Part A Chem Anal Control Expo Risk Assess. 2012;29(8):1175-1182.

4. de Silva MN. Nanotechnology and nanomedicine: a new horizon for medical diagnostics and treatment. Arch Soc Esp Oftalmol. 2007;82(6): 331-334.

5. Wang Q, Yan J, Yang J, Li B. Nanomaterials promise better bone repair. Mater Today. 2016;19(8):451-463.

6. Wang X, Ding B, Li B. Biomimetic electrospun nanofibrous structures for tissue engineering. Mater Today (Kidlington). 2013;16(6): 229-241.

7. Zhao J, Castranova V. Toxicology of nanomaterials used in nanomedicine. J Toxicol Environ Health B Crit Rev. 2011;14(8): 593-632.

8. Crommelin DJA, Park K, Florence A. Pharmaceutical nanotechnology: unmet needs in drug delivery. J Control Release. 2010;141(3): 263-264.

9. Luo H, Jiang B, Li B, Li Z, Jiang BH, Chen YC. Kaempferol nanoparticles achieve strong and selective inhibition of ovarian cancer cell viability. Int J Nanomedicine. 2012;7:3951-3959.

10. Armstead AL, Li BY. Nanomedicine as an emerging approach against intracellular pathogens. Int J Nanomedicine. 2011;6:3281-3293.

11. Cassee FR, van Balen EC, Singh C, et al. Exposure, health and ecological effects review of engineered nanoscale cerium and cerium oxide associated with its use as a fuel additive. Crit Rev Toxicol. 2011;41(3): 213-229.

12. Lynam DR, Pfeifer GD, Fort BF, Gelbcke AA. Environmental assessment of MMT fuel additive. Sci Total Environ. 1990;93:107-114.

13. Madl AK, Unice K, Kreider M, Kovochich M, Bebenek IG. Health risk ranking framework for the life cycle of nanomaterial-containing products: comparison of industrial versus consumer application settings. Int J Toxicol. 2013;32(1):65-69.

14. Yan JH, Li BY, Liu XB. Nano-porous sulfur-polyaniline electrodes for lithium-sulfur batteries. Nano Energy. 2015;18:245-252.

15. Yan JH, Liu X, Yao M, Wang X, Wafle TK, Li B. Long-life, highefficiency lithium-sulfur battery from a nanoassembled cathode. Chem Mater. 2015;27(14):5080-5087.

16. Yan JH, Liu X, Wang X, Li B. Long-life, high-efficiency lithium/sulfur batteries from sulfurized carbon nanotube cathodes. J Mater Chem A. 2015;3(18):10127-10133

17. Yan JH, Liu XB, Li BY. Nano-assembled Na2FePO4F/carbon nanotube multi-layered cathodes for Na-ion batteries. Electrochem Commun. 2015;56:46-50.

18. Adlakha-Hutcheon G, Khaydarov R, Korenstein R, et al. Nanomaterials, nanotechnology: applications, consumer products, and benefits. In: Linkov I, Steevens J, editors. Nanomaterials: Risks and Benefits. Dordrecht, the Netherlands: Springer; 2009:195-207.

19. Consumer Product Summary: Project on Emerging Nanotechnologies. Available from: http://www.nanotechproject.org/cpi/about/analysis/. Accessed September 14, 2014.

20. Eckelman MJ, Mauter MS, Isaacs JA, Elimelech M. New perspectives on nanomaterial aquatic ecotoxicity: production impacts exceed direct exposure impacts for carbon nanotoubes. Environ Sci Technol. 2012;46(5):2902-2910. 
21. Gaiser BK, Fernandes T, Jepson M, Lead JR, Tyler CR, Stone V. Assessing exposure, uptake and toxicity of silver and cerium dioxide nanoparticles from contaminated environments. Environ Health. 2009; 8(Suppl 1):S2.

22. Buzea C, Pacheco II, Robbie K. Nanomaterials and nanoparticles: sources and toxicity. Biointerphases. 2007;2(4):Mr17-Mr71.

23. Keegan GM, Learmonth ID, Case CP. A systematic comparison of the actual, potential, and theoretical health effects of cobalt and chromium exposures from industry and surgical implants. Crit Rev Toxicol. 2008; 38(8):645-674.

24. Sansone V, Pagani D, Melato M. The effects on bone cells of metal ions released from orthopaedic implants. A review. Clin Cases Miner Bone Metab. 2013;10(1):34-40.

25. Simeonova PP, Erdely A. Engineered nanoparticle respiratory exposure and potential risks for cardiovascular toxicity: predictive tests and biomarkers. Inhal Toxicol. 2009;21(Suppl 1):68-73.

26. Cattaneo AG, Gornati R, Sabbioni E, et al. Nanotechnology and human health: risks and benefits. $J$ Appl Toxicol. 2010;30(8):730-744.

27. Stapleton PA, Minarchick VC, McCawley M, Knuckles TL, Nurkiewicz TR. Xenobiotic particle exposure and microvascular endpoints: a call to arms. Microcirculation. 2012;19(2):126-142.

28. Nel AE, Mädler L, Velegol D, et al. Understanding biophysicochemical interactions at the nano-bio interface. Nat Mater. 2009;8(7) 543-557.

29. Song Y, Li X, Wang L, et al. Nanomaterials in humans: identification, characteristics, and potential damage. Toxicol Pathol. 2011;39(5): 841-849.

30. Nurkiewicz TR, Porter DW, Hubbs AF, et al. Pulmonary particulate matter and systemic microvascular dysfunction. Res Rep Health Eff Inst 2011;164:3-48.

31. Gill HS, Grammatopoulos G, Adshead S, Tsialogiannis E, Tsiridis E. Molecular and immune toxicity of CoCr nanoparticles in MoM hip arthroplasty. Trends Mol Med. 2012;18(3):145-155.

32. Ingham E, Fisher J. Biological reactions to wear debris in total joint replacement. Proc Inst Mech Eng H. 2000;214(H1):21-37.

33. Donaldson K, Schinwald A, Murphy F, et al. The biologically effective dose in inhalation nanotoxicology. Acc Chem Res. 2013;46(3):723-732.

34. Hubbs AF, Mercer RR, Benkovic SA, et al. Nanotoxicology - a pathologist's perspective. Toxicol Pathol. 2011;39(2):301-324.

35. Lison D, Vietti G, van den Brule S. Paracelsus in nanotoxicology. Part Fibre Toxicol. 2014;11(1):35.

36. Takhar $\mathrm{P}$, Mahant $\mathrm{S}$. In vitro methods for nanotoxicity assessment: advantages and applications. Arch Appl Sci Res. 2011;3(2):389-403.

37. Kroll A, Pillukat MH, Hahn D, Schnekenburger J. Interference of engineered nanoparticles with in vitro toxicity assays. Arch Toxicol. 2012;86(7):1123-1136.

38. Lupu AR, Popescu T. The noncellular reduction of MTT tetrazolium salt by $\mathrm{TiO}(2)$ nanoparticles and its implications for cytotoxicity assays. Toxicol In Vitro. 2013;27(5):1445-1450.

39. Guadagnini R, Halamoda Kenzaoui B, Walker L, et al. Toxicity screenings of nanomaterials: challenges due to interference with assay processes and components of classic in vitro tests. Nanotoxicology. 2015;9(Suppl 1):13-24.

40. Fischer HC, Chan WCW. Nanotoxicity: the growing need for in vivo study. Curr Opin Biotechnol. 2007;18(6):565-571.

41. Henderson RF, Driscoll KE, Harkema JR, et al. A comparison of the inflammatory response of the lung to inhaled versus instilled particles in F344 rats. Fundam Appl Toxicol. 1995;24(2):183-197.

42. Yao Z, Stiglich J, Sudarshan T. Nanosized WC-Co holds promise for the future. Metal Powder Report. 1998;53(3):26-33.

43. Yao Z, Stiglich J, Sudarshan T. Nano-grained tungsten carbide-cobalt (WC/Co). Materials Modification Inc.; 1995:1-27. Available from: http://www.matmod.com/publications/armor_1.pdf. Accessed October 21, 2014.

44. Linnainmaa M, Kangas J, Kalliokoski P. Exposure to airborne metals in the manufacture and maintenance of hard metal and stellite blades. Am Ind Hyg Assoc J. 1996;57(2):196-201.
45. Stefaniak AB, Virji MA, Day GA. Characterization of exposures among cemented tungsten carbide workers. Part I: Size-fractionated exposures to airborne cobalt and tungsten particles. J Expo Sci Environ Epidemiol. 2009;19(5):475-491.

46. National Toxicology Program. Cobalt-tungsten carbide: powders and hard metals. Rep Carcinog. 2011;12:115-120.

47. Demedts M, Ceuppens JL. Respiratory diseases from hard metal or cobalt exposure. Solving the enigma. Chest. 1989;95(1):2-3.

48. Kumagai S, Kusaka Y, Goto S. Cobalt exposure level and variability in the hard metal industry of Japan. Am Ind Hyg Assoc J. 1996;57(4): 365-369.

49. Kusaka Y, Goto S. Is there an occupational exposure limit (TLV) present for cobalt? A lesson from hard metal disease in Japan. Adv Prev Occup Respir Dis. 1998;1153:388-392.

50. Kraus T, Schramel P, Schaller KH, Zöbelein P, Weber A, Angerer J. Exposure assessment in the hard metal manufacturing industry with special regard to tungsten and its compounds. Occup Environ Med. 2001;58(10):631-634.

51. Anttila S, Sutinen S, Paananen M, et al. Hard metal lung disease: a clinical, histological, ultrastructural and X-ray microanalytical study. Eur J Respir Dis. 1986;69(2):83-94.

52. Galy $\mathrm{P}$, Bourret $\mathrm{P}$, Tolot $\mathrm{P}$, et al. Pulmonary disorders in the hard metal industry. Rev Inst Hyg Mines (Hasselt). 1974;29(3):130-137.

53. Hartung M. Etiology, pathogenesis and clinical aspects of hard metal fibrosis of the lung. Pneumologie. 1990;44(2):49-54.

54. Lasfargues G, Wild P, Moulin JJ, et al. Lung cancer mortality in a French cohort of hard-metal workers. Am J Ind Med. 1994;26(5): 585-595.

55. Meyer-Bisch C, Pham QT, Mur JM, et al. Respiratory hazards in hard metal workers: a cross sectional study. Br J Ind Med. 1989;46(5): 302-309.

56. Moulin JJ, Wild P, Romazini S, et al. Lung cancer risk in hard-metal workers. Am J Epidemiol. 1998;148(3):241-248.

57. Nemery B, Verbeken EK, Demedts M. Giant cell interstitial pneumonia (hard metal lung disease, cobalt lung). Semin Respir Crit Care Med. 2001;22(4):435-448.

58. Rivolta G, Nocoli E, Ferretti G, Tomasini M. Hard metal lung disorders: analysis of a group of exposed workers. Sci Total Environ. 1994;150(1-3): 161-165.

59. Rochat T, Kaelin RM, Batawi A, Junod AF. Rapidly progressive interstitial lung disease in a hard metal coating worker undergoing hemodialysis. Eur J Respir Dis. 1987;71(1):46-51.

60. Forni A. Bronchoalveolar lavage in the diagnosis of hard metal disease. Sci Total Environ. 1994;150(1-3):69-76.

61. Kinoshita M, Sueyasu Y, Watanabe H, et al. Giant cell interstitial pneumonia in two hard metal workers: the role of bronchoalveolar lavage in diagnosis. Respirology. 1999;4(3):263-266.

62. Dunlop P, Müller NL, Wilson J, Flint J, Churg A. Hard metal lung disease: high resolution $\mathrm{CT}$ and histologic correlation of the initial findings and demonstration of interval improvement. J Thorac Imaging. 2005;20(4):301-304.

63. Moriyama H, Kobayashi M, Takada T, et al. Two-dimensional analysis of elements and mononuclear cells in hard metal lung disease. Am J Respir Crit Care Med. 2007;176(1):70-77.

64. Potolicchio I, Mosconi G, Forni A, Nemery B, Seghizzi P, Sorrentino R. Susceptibility to hard metal lung disease is strongly associated with the presence of glutamate 69 in HLA-DP beta chain. Eur J Immunol. 1997;27(10):2741-2743.

65. Tanaka J, Moriyama H, Terada M, et al. An observational study of giant cell interstitial pneumonia and lung fibrosis in hard metal lung disease. BMJ Open. 2014;4(3):e004407.

66. Nureki S, Miyazaki E, Nishio S, Ando M, Kumamoto T. Hard metal lung disease successfully treated with inhaled corticosteroids. Intern Med. 2013;52(17):1957-1961.

67. Enriquez LS, Mohammed TL, Johnson GL, Lefor MJ, Beasley MB. Hard metal pneumoconiosis: a case of giant-cell interstitial pneumonitis in a machinist. Respir Care. 2007;52(2):196-199. 
68. Blanc PD. Is giant cell interstitial pneumonitis synonymous with hard metal lung disease? Am J Respir Crit Care Med. 2007;176(8):834; author reply 834-835.

69. Naqvi AH, Hunt A, Burnett BR, Abraham JL. Pathologic spectrum and lung dust burden in giant cell interstitial pneumonia (hard metal disease/cobalt pneumonitis): review of 100 cases. Arch Environ Occup Health. 2008;63(2):51-70.

70. Tabatowski K, Roggli VL, Fulkerson WJ, Langley RL, Benning T, Johnston WW. Giant cell interstitial pneumonia in a hard-metal worker. Cytologic, histologic and analytical electron microscopic investigation. Acta Cytol. 1988;32(2):240-246.

71. Lison D, Lauwerys R, Demedts M, Nemery B. Experimental research into the pathogenesis of cobalt/hard metal lung disease. Eur Respir J. 1996;9(5):1024-1028.

72. Huaux F, Lardot C, Arras M, et al. Lung toxicity of hard metal particles and production of interleukin-1, tumor necrosis factor-alpha, fibronectin, and cystatin-c by lung phagocytes. Toxicol Appl Pharmacol. 1995; 132(1):53-62.

73. Antonini JM, Starks K, Roberts JR, Millecchia L, Yang HM, Rao KM. Changes in F-actin organization induced by hard metal particle exposure in rat pulmonary epithelial cells using laser scanning confocal microscopy. In Vitro Mol Toxicol. 2000;13(1):5-16.

74. Bastian S, Busch W, Kühnel D, et al. Toxicity of tungsten carbide and cobalt-doped tungsten carbide nanoparticles in mammalian cells in vitro. Environ Health Perspect. 2009;117(4):530-536.

75. Busch W, Kühnel D, Schirmer K, Scholz S. Tungsten carbide cobalt nanoparticles exert hypoxia-like effects on the gene expression level in human keratinocytes. BMC Genomics. 2010;11:65.

76. Edel J, Sabbioni E, Pietra R, et al. Trace metal lung disease: in vitro interaction of hard metals with human lung and plasma components. Sci Total Environ. 1990;95:107-117.

77. Fenoglio I, Corazzari I, Francia C, Bodoardo S, Fubini B. The oxidation of glutathione by cobalt/tungsten carbide contributes to hard metalinduced oxidative stress. Free Radic Res. 2008;42(8):437-445.

78. Kuhnel D, Scheffler K, Wellner P, et al. Comparative evaluation of particle properties, formation of reactive oxygen species and genotoxic potential of tungsten carbide based nanoparticles in vitro. $J$ Hazard Mater. 2012;227-228:418-426.

79. Lison D, Carbonnelle P, Mollo L, Lauwerys R, Fubini B. Physicochemical mechanism of the interaction between cobalt metal and carbide particles to generate toxic activated oxygen species. Chem Res Toxicol. 1995;8(4):600-606.

80. Lison D, Lauwerys R. Study of the mechanism responsible for the elective toxicity of tungsten carbide-cobalt powder toward macrophages. Toxicol Lett. 1992;60(2):203-210.

81. Lombaert N, Castrucci E, Decordier I, et al. Hard-metal (WC-Co) particles trigger a signaling cascade involving p38 MAPK, HIF-1alpha, HMOX1, and p53 activation in human PBMC. Arch Toxicol. 2012; 87(2):259-268.

82. Lombaert N, Lison D, Van Hummelen P, Kirsch-Volders M. In vitro expression of hard metal dust (WC-Co) - responsive genes in human peripheral blood mononucleated cells. Toxicol Appl Pharmacol. 2008; 227(2):299-312

83. Anard D, Kirsch-Volders M, Elhajouji A, Belpaeme K, Lison D. In vitro genotoxic effects of hard metal particles assessed by alkaline single cell gel and elution assays. Carcinogenesis. 1997;18(1):177-184.

84. Ding M, Kisin ER, Zhao J, et al. Size-dependent effects of tungsten carbide-cobalt particles on oxygen radical production and activation of cell signaling pathways in murine epidermal cells. Toxicol Appl Pharmacol. 2009;241(3):260-268.

85. Zhang XD, Zhao J, Bowman L, Shi X, Castranova V, Ding M. Tungsten carbide-cobalt particles activate Nrf2 and its downstream target genes in JB6 cells possibly by ROS generation. $J$ Environ Pathol Toxicol Oncol. 2010;29(1):31-40.

86. Armstead AL, Arena CB, Li B. Exploring the potential role of tungsten carbide cobalt (WC-Co) nanoparticle internalization in observed toxicity toward lung epithelial cells in vitro. Toxicol Appl Pharmacol. 2014;278(1):1-8
87. Armstead AL, Li B. In vitro inflammatory effects of hard metal (WC-Co) nanoparticle exposure. Int J Nanomedicine. 2016;11:6195-6206.

88. Liu LZ, Ding M, Zheng JZ, et al. Tungsten carbide-cobalt nanoparticles induce reactive oxygen species, AKT, ERK, AP-1, NF-kappaB, VEGF, and angiogenesis. Biol Trace Elem Res. 2015;166(1):57-65.

89. Kitamura H, Yoshimura Y, Tozawa T, Koshi K. Effects of cemented tungsten carbide dust on rat lungs following intratracheal injection of saline suspension. Acta Pathol Jpn. 1980;30(2):241-253.

90. Lasfargues G, Lardot C, Delos M, Lauwerys R, Lison D. The delayed lung responses to single and repeated intratracheal administration of pure cobalt and hard metal powder in the rat. Environ Res. 1995;69(2): 108-121.

91. Lasfargues G, Lison D, Maldague P, Lauwerys R. Comparative study of the acute lung toxicity of pure cobalt powder and cobalt-tungsten carbide mixture in rat. Toxicol Appl Pharmacol. 1992;112(1):41-50.

92. De Boeck M, Hoet P, Lombaert N, Nemery B, KirschVolders M, Lison D. In vivo genotoxicity of hard metal dust: induction of micronuclei in rat type II epithelial lung cells. Carcinogenesis. 2003;24(11):1793-1800.

93. Fedan JS, Cutler D. Hard metal-induced disease: effects of metal cations in vitro on guinea pig isolated airways. Toxicol Appl Pharmacol. 2001;174(3):199-206.

94. Rengasamy A, Kommineni C, Jones JA, Fedan JS. Effects of hard metal on nitric oxide pathways and airway reactivity to methacholine in rat lungs. Toxicol Appl Pharmacol. 1999;157(3):178-191.

95. Adamis Z, Tátrai E, Honma K, Kárpáti J, Ungváry G. A study on lung toxicity of respirable hard metal dusts in rats. Ann Occup Hyg. 1997;41(5):515-526.

96. Armstead AL, Minarchick VC, Porter DW, Nurkiewicz TR, Li B. Acute inflammatory responses of nanoparticles in an intra-tracheal instillation rat model. PLoS One. 2015;10(3):e0118778.

97. Kerfoot EJ, Fredrick WG, Domeier E. Cobalt metal inhalation studies on miniature swine. Am Ind Hyg Assoc J. 1975;36(1):17-25.

98. Lison D, Lauwerys R. Evaluation of the role of reactive oxygen species in the interactive toxicity of carbide-cobalt mixtures on macrophages in culture. Arch Toxicol. 1993;67(5):347-351.

99. Roesems G, Hoet PH, Dinsdale D, Demedts M, Nemery B. In vitro cytotoxicity of various forms of cobalt for rat alveolar macrophages and type II pneumocytes. Toxicol Appl Pharmacol. 2000;162(1):2-9.

100. Lison D, Lauwerys R. Cobalt bioavailability from hard metal particles. Further evidence that cobalt alone is not responsible for the toxicity of hard metal particles. Arch Toxicol. 1994;68(8):528-531.

101. Lombaert N, De Boeck M, Decordier I, Cundari E, Lison D, KirschVolders M. Evaluation of the apoptogenic potential of hard metal dust (WC-Co), tungsten carbide and metallic cobalt. Toxicol Lett. 2004; 154(1-2):23-34.

102. Albanese A, Tang PS, Chan WC. The effect of nanoparticle size, shape, and surface chemistry on biological systems. Annu Rev Biomed Eng. 2012;14:1-16.

103. Geiser M. Morphological aspects of particle uptake by lung phagocytes. Microsc Res Tech. 2002;57(6):512-522.

104. Gauldie J, Jordana M, Cox G. Cytokines and pulmonary fibrosis. Thorax. 1993;48(9):931-935.

105. Park B, Donaldson K, Duffin R, et al. Hazard and risk assessment of a nanoparticulate cerium oxide-based diesel fuel additive - a case study. Inhal Toxicol. 2008;20(6):547-566.

106. Papageorgiou I, Brown C, Schins R, et al. The effect of nano- and micron-sized particles of cobalt-chromium alloy on human fibroblasts in vitro. Biomaterials. 2007;28(19):2946-2958.

107. Papageorgiou I, Shadrick V, Davis S, et al. Macrophages detoxify the genotoxic and cytotoxic effects of surgical cobalt chrome alloy particles but not quartz particles on human cells in vitro. Mutat Res. 2008; 643(1-2):11-19.

108. Papageorgiou I, Yin Z, Ladon D, et al. Genotoxic effects of particles of surgical cobalt chrome alloy on human cells of different age in vitro. Mutat Res. 2007;619(1-2):45-58.

109. Sun L, Li Y, Liu X, et al. Cytotoxicity and mitochondrial damage caused by silica nanoparticles. Toxicol In Vitro. 2011;25(8):1619-1629. 
110. Park EJ, Yi J, Chung KH, Ryu DY, Choi J, Park K. Oxidative stress and apoptosis induced by titanium dioxide nanoparticles in cultured BEAS-2B cells. Toxicol Lett. 2008;180(3):222-229.

111. Wilhelmi V, Fischer U, van Berlo D, Schulze-Osthoff K, Schins RP, Albrecht C. Evaluation of apoptosis induced by nanoparticles and fine particles in RAW 264.7 macrophages: facts and artefacts. Toxicol In Vitro. 2012;26(2):323-334.

112. Blum JL, Rosenblum LK, Grunig G, Beasley MB, Xiong JQ, Zelikoff JT. Short-term inhalation of cadmium oxide nanoparticles alters pulmonary dynamics associated with lung injury, inflammation, and repair in a mouse model. Inhal Toxicol. 2014;26(1):48-58.

113. Pauluhn J. Subchronic inhalation toxicity of iron oxide (magnetite, $\mathrm{Fe}(3) \mathrm{O}(4)$ ) in rats: pulmonary toxicity is determined by the particle kinetics typical of poorly soluble particles. J Appl Toxicol. 2012;32(7): 488-504.

114. Minarchick VC, Stapleton PA, Porter DW, et al. Pulmonary cerium dioxide nanoparticle exposure differentially impairs coronary and mesenteric arteriolar reactivity. Cardiovasc Toxicol. 2013;13(4): 323-337.

115. Choi M, Cho M, Han BS, et al. Chitosan nanoparticles show rapid extrapulmonary tissue distribution and excretion with mild pulmonary inflammation to mice. Toxicol Lett. 2010;199(2):144-152.

116. Brown C, Lacharme-Lora L, Mukonoweshuro B, et al. Consequences of exposure to peri-articular injections of micro- and nano-particulate cobalt-chromium alloy. Biomaterials. 2013;34(34):8564-8580.
117. Wang Z, Chen Z, Zuo Q, et al. Reproductive toxicity in adult male rats following intra-articular injection of cobalt-chromium nanoparticles. J Orthop Sci. 2013;18(6):1020-1026.

118. Gaiser BK, Biswas A, Rosenkranz P, et al. Effects of silver and cerium dioxide micro- and nano-sized particles on Daphnia magna. J Environ Monit. 2011;13(5):1227-1235.

119. De Boeck M, Lombaert N, De Backer S, Finsy R, Lison D, KirschVolders M. In vitro genotoxic effects of different combinations of cobalt and metallic carbide particles. Mutagenesis. 2003;18(2):177-186.

120. Kuhnel D, Buscha W, Meißnerb T, et al. Agglomeration of tungsten carbide nanoparticles in exposure medium does not prevent uptake and toxicity toward a rainbow trout gill cell line. Aquat Toxicol. 2009; 93(2-3):91-99.

121. Lison D, Lauwerys R. In vitro cytotoxic effects of cobalt-containing dusts on mouse peritoneal and rat alveolar macrophages. Environ Res. 1990;52(2):187-198.

122. Lison D, Lauwerys R. Biological responses of isolated macrophages to cobalt metal and tungsten carbide-cobalt powders. Pharmacol Toxicol. 1991;69(4):282-285.

123. Lison D, Lauwerys R. The interaction of cobalt metal with different carbides and other mineral particles on mouse peritoneal macrophages Toxicol In Vitro. 1995;9(3):341-347.
International Journal of Nanomedicine

\section{Publish your work in this journal}

The International Journal of Nanomedicine is an international, peerreviewed journal focusing on the application of nanotechnology in diagnostics, therapeutics, and drug delivery systems throughout the biomedical field. This journal is indexed on PubMed Central, MedLine, CAS, SciSearch $®$, Current Contents $\AA /$ Clinical Medicine,

\section{Dovepress}

Journal Citation Reports/Science Edition, EMBase, Scopus and the Elsevier Bibliographic databases. The manuscript management system is completely online and includes a very quick and fair peer-review system, which is all easy to use. Visit http://www.dovepress.com/ testimonials.php to read real quotes from published authors. 